\title{
World trends and Canadian forest policy: Exploring the influence of consumers, environmental group activity, international trade rules and world forestry negotiations ${ }^{1}$
}

\author{
by Steven Bernstein ${ }^{2}$ and Benjamin Cashore ${ }^{3}$
}

\section{Introduction}

Canadian forest policy has come under intense and sustained international scrutiny in the last decade as concerns about the forest environment increased dramatically in western industrialized countries. This paper assesses the impact of these international pressures by exploring the ways in which organized interests (transnational environmental groups, buyers groups and consumers), international rules/institutions and ideas/norms have helped to shape Canadian forest policy. The varying degrees of influence each of these international forces exert are determined partly by the policy arenas with which they interact. We focus on three policy areas to illustrate this point: the Canada-US softwood lumber dispute, international forest negotiations, and international forest certification efforts. First, we make an important distinction between the effects of "globalization" and "internationalization" to put these influences in context.

\section{Globalization and Internationalization}

Following Doern et al. (1996:2), "internationalization" is defined as the phenomenon whereby policies within domestic jurisdictions face increased scrutiny and participation from actors and/or institutions outside of those jurisdictions. We restrict the definition of globalization to structural economic factors, mainly "rising levels of trade, finance and foreign direct investment (FDI) (Berger 1996:9)." Globalization is often thought to affect domestic politics, institutions and policy outputs by putting downward pressure on "wages, working conditions ... or environmental protection," causing companies to move to countries with lower wages, taxes, and regulations (Berger 1996:12). Certainly the Canadian forest sector, as the world's largest exporter of forest products and recipient of a significant degree of foreign direct investment, can be considered "globalized." The forest sector also makes the largest single contribution to Canada's balance of payments surplus, contributing $\$ 2.1$ billion in 1997 to provincial coffers in the form of resource rents (Natural Resources Canada 1997). Yet, globalization did not produce the predicted effects in the last ten years. Instead, Canada experienced an upward movement in environmental regulations and forest stewardship policies. Examples include British Columbia's Forest Practices Code Act, provincial protected area programs, the National Forest Sector Strategy's Sustainable Forestry Principles, forest certification efforts, and MacMillan Bloedel's announcement to

\footnotetext{
${ }^{1}$ Based on a presentation to the 90 th Annual General Meeting of the Canadian Institute of Forestry, 5 October 1998.

${ }^{2}$ Postdoctoral Fellow, Mershon Center, Ohio State University,1501 Neil Avenue, Columbus, OH 43201. E-mail: bernstein.39@osu.edu

${ }^{3}$ Assistant Professor, School of Forestry, 203 M. White Smith Hall, Auburn

University, AL 36849-5418. E-mail: cashore@ forestry.auburn.edu
}

phase out clearcutting on oldgrowth forests.

We argue that whereas globalization clearly affected the way international forces shaped Canadian forest policy, the direct source of those pressures came instead from factors we group under interationalization. Pressures affecting Canadian forest management and forest policy came not from the market per se, but from international rules, organizations and transnational and domestic environmental groups. For example, environmental groups used the market by targeting consumers and organizing buyers groups. Thus, globalization played an enabling role to internationalization because the international pressure came largely from boycott threats and import duties, neither of which would have been

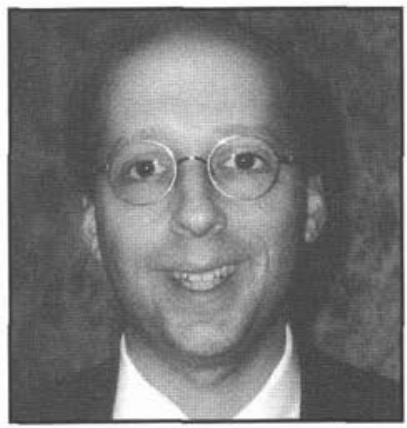

Steven Bernstein

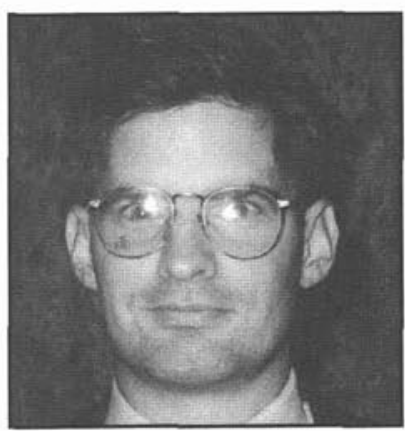

Benjamin Cashore effective without a globalized Canadian forest sector. Internationalization, not globalization, determined the direction these pressures pushed, reversing globalization's predicted downward effects.

\section{The Softwood Lumber Dispute}

Since 1982, Canada and the United States have been involved in an unrelenting dispute over Canadian exports of softwood lumber. A claim by US forest companies that Canadian provinces subsidize their forest industries by charging below market prices (stumpage rates) for the rights to harvest provincially-owned timber lies at the heart of the dispute. This belief led US forest companies to launch three different countervail proceedings under US trade law in 1982, 1986 and 1991.

In 1983, the US Commerce Department's International Trade Administration (ITA) ruled that Canadian provinces were not providing a subsidy, but reversed its decision three years later, preliminarily finding that a subsidy did exist (Horlick and Oliver 1989). The 1986 ruling set off a series of debates in Canada about resource subsidies, and gave credibility and influence to those who had long demanded that the forest industry pay more for the right to harvest publicly-owned timber (Cashore 1997a). The 1986 ruling also set the stage for "compromise agreements" whereby the US would abandon countervail 
proceedings if Canada would agree to "voluntary export restraints" (VERs). In 1986, Canada and the US signed a VER known as the "Memorandum of Understanding" (MOU) under which Canada agreed to impose an export tax on its softwood lumber. This agreement meant that monies collected from the tax would go to provincial coffers instead of the US treasury.

The Canadian government cancelled the MOU in 1991, after key provinces raised their stumpage fees. This sparked the third countervail determination. Once again the ITA found that provinces did subsidize their forest industries and the International Trade Commission (ITC) ruled this subsidy injured US producers. An import tax was imposed on Canadian lumber imports from British Columbia, Alberta, Ontario and Quebec. Canada immediately appealed these rulings to bi-national panels under the Canada-US Free Trade Agreement dispute resolution procedures. The panels eventually ruled that the ITA and ITC lacked adequate information to support their rulings. The US subsequently dropped the import tax and refunded monies already collected. Members of Congress argued, however, that the panels misunderstood US trade law. They quickly modified the law to remove the likelihood that Canada would win any future appeals. This set the stage for a fourth countervail, which Canada avoided by accepting another VER. The new Canada-US Softwood Lumber Agreement (SLA) committed Canada to a system of "quotas" for lumber headed to the US market, with exports above the quota subject to an export tax.

\section{Effects on Canadian Forest Policy}

Throughout these developments, a debate raged in Canada about the level of stumpage rates the four main lumber exporting provinces (British Columbia, Alberta, Quebec and Ontario) charged their forest companies to harvest provincially-owned forest land. The debate was most heated in British Columbia, where softwood lumber exports to the US outnumber exports from all other provinces combined. In the mid-1980s, the balance of power began to shift in favour of those who argued that forest companies did not pay a fair price for publicly-owned timber, as cash-strapped provincial governments saw higher stumpage fees as an opportunity to solve their budgetary problems (Cashore 1997a; Groen 1994). This paved the way for "structural" increases in British Columbia's provincial stumpage fees in 1987 and 1994.

By the 1990s, the debate in both countries took on an environmental flavour. The US lumber lobby, which raised this issue with members of Congress, criticized Canadian provinces' environmental forestry records. The US industry argued that Canadian forest companies were not subject to the same environmental restrictions they now faced on US national forest lands. ${ }^{4}$ The Softwood Lumber Agreement also increased attention to environmental forestry policy, as Canadian environmental groups saw the SLA's non-derogation clause as a tool with which to challenge efforts to streamline British Columbia's Forest Practices Code (Hamilton 1997; Schreiner and Morton 1997).

British Columbia and Canadian forest policy has shown instances of resilience and acquiescence to these US trade

\footnotetext{
${ }^{4}$ Cashore (1997a) These arguments were made in order to maintain their influence in Congress. The ITA and ITC adjucation processes cannot officially take environmental issues into account.
}

pressures. On one hand, Canadian stumpage rates increased in response to US pressure, moving stumpage fees higher. In fact, many now argue that BC's rates are above market value, much higher than many in the US and in Eastern Canada. On the other hand, the policy instrument for deciding stumpage fees in key exporting provinces remains government-driven rather than market driven, and the underlying form of harvesting remains long-term forest licences (tenure agreements). ${ }^{5}$ The softwood dispute reveals that Canadian provinces will use these international pressures to force their own policy agendas, whether designed to increase stumpage charges or introduce sweeping changes to existing forestry policy. As long as Canadian provinces maintain a non-market system for calculating resource rents and as long as Canadian softwood lumber exports to the US remain at current levels, the softwood trade dispute will persist. Federal and provincial governments will continue to use the dispute in the political arena as a way of charging US "harassment," and astute governments and organized interests will use these pressures to help develop and implement their own policy agendas.

\section{International Institutions and Forestry}

Because few formal rules apply, international institutions do not influence the forest sector as directly as trade policy does. However, the international norms and networks that have developed since the late 1980 s exert significant pressures on Canadian forest policy development. We can trace these pressures back to the 1980 s, when Northern countries and environmentalists focused their attention on tropical deforestation. This pressure helped secure the inclusion of a mandate to conserve tropical forests and their genetic resources in the International Tropical Timber Agreement (ITTA) of 1983, and its highest decision-making body, the International Tropical Timber Organization (ITTO), even though their primary mandate remained the regulation of trade in tropical timber) (Humphreys 1996:233). Then, in 1990, tropical timber producer countries adopted Target 2000 - the date by which tropical timber traded internationally should come from "sustainable" sources. After prolonged negotiations on a successor agreement (the ITTA 1994), consumer countries, including Canada, pledged to manage their own forests sustainably by the year 2000 , but outside the context of the ITTO. They reasoned that a pledge within the ITTO would undermine the prospects for a global forest convention, which they wanted to be much broader than the trade-focused ITTA.

Interest in a global forest convention took shape in the leadup to the 1992 Earth Summit in Rio de Janeiro. Canada became one of its strongest proponents, and made negotiation of a convention a major goal of the international plank of Canada's National Forest Strategy for 1998-2003. ${ }^{6}$ Such a convention would provide Canadian producers and governments with a stable set of rules to guide trade in forest products, ensure access to markets, and would spell out commitments for forest man-

\footnotetext{
${ }^{5}$ Large forest companies were given long-term rights to harvest a particular area. In exchange, the companies were required to manage the land on a longterm, "sustained yield" basis. Companies were also required under these arrangements to operate mills and create employment .

${ }^{6}$ See Canadian Council of Forest Ministers (1998). For up-to-date summaries of multilateral negotiations on forests, see, International Institute for Sustainable Development (1988) available from their web site at www.iisd.ca.
} 
agement. However, the G-77/China bloc remained suspicious of Northern intentions on several fronts and refused at The Earth Summit to even consider a binding agreement. Sovereignty was a key stumbling block, as were trade-related issues. Northern states, such as the United States and Canada, argued for a "global responsibility" approach, while Malaysia and India argued for "sovereign discretion." They feared Northern states would dictate how forests within the jurisdiction of Southern states should be managed (Porter and Brown 1996:126). Developing countries were also concerned about inadequate financial and technology transfer commitments from the North that they argued were required to aid the South in its sustainability obligations (Humphreys 1996; Porter and Brown 1996: 115-129; Williams 1993).

What resulted instead of a global forest convention was a "Non-legally binding authoritative statement of principles for global consensus on the management, conservation and sustainable development of all types of forests," known as the "forest principles (IDRC 1993)." Although non-binding, the agreement is important for its support for principles of biodiversity and the maintenance of ecological processes, and for recognizing the role of forests as fulfilling economic and social needs. However, as the title suggests, the contradictory nature of some of these goals was left unresolved.

Despite various attempts since 1992 to reinvigorate movement toward a convention, all have failed. A variety of narrower and/or regional initiatives have taken shape since 1992 in its place. New initiatives include the Montreal Process on creating criteria and indicators $(\mathrm{C} \& \mathrm{I})$ for the conservation and sustainable development of temperate and boreal forests, the Helsinki Process on protecting forests in Europe (which includes a C\&I process), negotiations toward a successor to the ITTA, initiatives on labelling and certification schemes, and a number of expert and governmental forestry workshops. $^{7}$

\section{Effects on Forest Policy in Canada}

Owing to non-binding and weak international rules, the indirect influence of norms and ideas generated by international institutions and negotiation processes affect Canadian forest policy more than direct regulation. For example, the 12 percent land protection commitment of BC's Protected Area Strategy comes from the 1987 World Commission on Environment and Development report's (1987:Ch.6) call for a tripling of the world's protected areas from the then current 4 per cent. The "Statement of Forest Principles" and 1992 Convention on Biological Diversity also influenced the norms embodied in BC's Forest Practice Code's biodiversity guidelines. Related concepts such as "ecosystem management" became the forest management system embraced in BC's Clayoquot Sound, whose slated logging had come under international criticism in 1993 (Scientific Panel for Sustainable Forest Practices in Clayoquot Sound 1994).

\footnotetext{
${ }^{7}$ The only process to focus serious attention on a global convention was the Intergovernmental Panel on Forests (IPF) in 1995, sponsored by the UN Commission on Sustainable Development (CSD). After two years of discussions that failed to reach consensus on a number of key issues, the Intergovernmental Forum on Forests (IFF) succeeded the IPF. Obstacles concerning trade, sovereignty, and aid continue to plague IFF discussions, suggesting progress towards a forest convention will remain slow (IISD 1995; IISD 1998).
}

At the national level, the Canadian Council of Forest Minister's National Forest Strategy: 1998-2003 was also clearly influenced by international developments. The report notes that the development of the National Forest Sector Strategy was "instrumental to Canadian representations at the 1992 United Nations Conference on the Environment and Development (UNCED)" and that this allowed Canada to argue in the international sphere that it was a leader in sustainable forest management (Canadian Council of Forest Ministers 1998:3). The latest report also focuses Canadian forest policy on the "forest ecosystem," something absent in its 1987 National Forest Sector Strategy. The 1998 report acknowledges that the Brundtland Commission and the emergence of other international norms caused the council to consider the forest ecosystem and social, cultural forest values alongside economic ones (Canadian Council of Forest Ministers 1998:2).

Owing to increased international awareness, transnational environmental groups have used BC's dependence on foreign markets to launch well-publicized boycott campaigns, first aimed at Clayoquot Sound, but later expanded to other regions of BC (Canadian Press 1998; Greenpeace Canada, Greenpeace International, and Greenpeace San Francisco 1997). These pressures influenced $\mathrm{BC}$ policy change by aiding the $\mathrm{BC}$ government of the early- to mid-1990s to carry out its forest practices and land use reforms, despite resistance from powerful domestic interests. ${ }^{8}$ Environmental groups could claim some success in their efforts to use the marketplace to force policy change.

Like the softwood lumber dispute, international forces do not only affect forest practices through direct domestic policy changes, but may facilitate government and organized interests to initiate and implement their own agendas.

\section{The Marketplace}

Following the failure to achieve a binding international forestry convention, environmental groups realized that by directly influencing the private sector they could more quickly and perhaps more effectively achieve sustainable forestry. Groups took a dual track approach: to continue the traditional but negative boycott efforts to force companies to change forest practices and/or purchasing habits by leading consumers away from their products; but also to launch a proactive certification scheme with the goal of leading consumers toward purchasing wood products harvested in an environmentally-friendly manner.

The most important initiative was the formation of the Forest Stewardship Council (FSC) in 1993, headquartered in Oaxaca, Mexico (Hansen 1998:19). Spearheaded by the World Wide Fund for Nature (WWF), FSC accredits organizations (certifiers) that must perform evaluations to see if a company's forest operation match ten established principles and criteria. More specific regional standards are then developed based on these broader principles. To date, FSC has accredited certification companies based in the United Kingdom, the Netherlands and the United States. The Silva Forest Foundation of BC is in the process of becoming FSC-certified (regional standards must still be developed), the Maritimes FSC standards process is close to completion, and a Canadian Working Group of the Forest Stewardship Council also exists (Drescher 1998).

Forest industry companies and associations in Canada began to develop their own "system-based" sustainable forestry

${ }^{8}$ Michael Harcourt, former Premier of British Columbia (1991-1995), 1996, personal interview. 
initiatives in response to FSC's emphasis on environmental performance. ${ }^{9}$ Critics argue that these industry processes are less effective because they focus on process, rather than performance, and because they involve industry associations certifying their own members rather than third parties (Gale and Burda 1997; Hansen 1998). Only the FSC process has the ultimate goal of providing an "eco-label" at the consumer level.

The future of certification is uncertain. While public opinion polls indicate that a large share of consumers are willing to pay a premium for certified wood products (Gale and Burda 1997; 430-431), the limited empirical data on consumer behaviour is less clear. Some companies report that they can obtain price premiums with certified wood, but not on a consistent basis (Hansen 1998:22). However, some companies embrace certification less for a price premium and more as a marketing technique to differentiate themselves from other companies. The goal of corporate differentiation may explain the success of the World Wide Fund for Nature in organizing the creation of buyers' groups in the UK, Holland, Belgium, Austria, and the United States (Hansen 1998).

Firm-level product differentiation goals may result in the increased use of FSC and other certification schemes. Recently, Canadian forest giant MacMillan Bloedel moved from a target of Greenpeace boycotts to a Greenpeace suitor, promising to halt clearcutting in old growth forests and to begin the process of FSC and CSA certification. Transnational environmental groups' end run around international discussions appeared to produce concrete results in this case. BC's Interfor, another target of transnational groups' boycott efforts, announced that it, too, wished to produce FSC-certified wood. ${ }^{10}$

These various certification schemes also provoked responses from federal and provincial governments, who have jointly outlined twelve principles they argue must be taken into account in any certification processes. ${ }^{11}$ Governments appear well aware that the appeal of certification as a solution to sustainable forestry stems precisely from its potential to bypass the sovereignty issue internationally and opposition to regulation domestically by operating in the marketplace independent of government regulation. Here, the authority rests with the power of buyers' groups and ultimately the consumer. Whether certification will always lead to "sustainably managed" forests ${ }^{12}$ and whether

\footnotetext{
${ }^{9}$ The Canadian Pulp and Paper Association developed a "Sustainable Forest Management System Standards" under the auspices of the Canadian Standards Association (CSA). The Alberta Forest Products Association developed a similar forest certification process entitled Forest Care, which has already certified Weyerhaeuser operations in Grand Prairie. These "systems-based" approaches are modelled after the International Standards Organization (ISO)'s 14001 Environmental Management System .

${ }^{10}$ Whereas CSA/ISO was trumpeted as a more viable alternative to FSC standards, some individual forest companies such as Weyerhaeuser Canada and Alberta Pacific now say CSA and FSC are both potentially attainable (personal interviews).

${ }^{11}$ Federal-Provincial Territorial Committee of Assistant Deputy Ministers on International Forest Issues (1996). These principles include that any certification system be complementary with government forest policies be "consistent with trade law and international principles." A key concern is that certification might be perceived as a "non-tariff barrier." The Dutch government's announcement that it is considering only allowing certified wood to be imported has augmented such fears.

${ }^{12}$ The Forest Stewardship Council has attempted to sidestep controversies over the term "sustainably-managed" forests focusing instead on "well-managed" forests.
}

a conflict will develop between certification and the criteria and indicators process noted above remains unclear. What is clear is that these international efforts have provoked responses by large forest companies in Canada.

\section{Conclusion}

While globalization enabled international forces to exert pressure on Canadian forest policy and management practices, the cause of this pressure did not come from the market itself, but from the more recent phenomenon of internationalization. The globalization/internationalization distinction allowed us to explore how Canadian forest policy faces increased international scrutiny from Canada-US forest trade disputes, international sustainable forestry initiatives, and international environmental groups boycott and certification campaigns, which have introduced the consumer as an important influence on Canadian forest policy.

The cumulative impact of these pressures on Canadian forest management and policy are mixed. The fundamental nature of the long-term "tenure system," which grants companies long term harvesting rights in return for "sustainable forest management," and the accompanying government-set stumpage rates has not changed, despite ongoing pressure from US forest companies to have Canadian provinces adopt a US-style competitive bidding system. The explanation for this policy rigidity is the "policy legacy" tenure systems create, with communities, revenues, and forest jobs becoming dependent on the existing forest management system. However, the softwood dispute has resulted in higher stumpage fees, most notably in British Columbia - the key target of US forest companies. We also found that short-term agreements to resolve the CanadaUS softwood lumber dispute actually limited the BC government's ability to reduce stumpage rates and made the province ponder the consequences of its efforts to streamline the Forest Practices Code.

Owing to the lack of an international forestry convention, international forestry agreements and processes have even less direct impact on Canadian forest management practices and policy. However, the norms and ideas raised in international forums affect the range of policy ideas considered and implemented by provincial and national governments. Environmental groups' interaction also increased through their participation in international processes. As a result, environmental groups were better able to organize boycott and certification efforts, both of which affected public and corporate Canadian forest policy.

Given the increasing complexity and fragmentation of international sustainable forestry issues it is difficult to predict the future direction of international forest policy. One thing appears certain: given Canada's dependence on world forest trade, Canadian forest policy will continue to come under international scrutiny. If Canada wants to shape and direct the type of pressure if faces, it must vigorously participate and be proactive in international discussions. The importance of the forest sector to Canada's economy, and its dependence on foreign markets for its products, make it unlikely that Canadian forest policy can operate independently of international pressures.

\section{Acknowledgements}

The authors thank Johanna den Hertog for sharing her expertise, ideas, and resources on this topic. Steven Bernstein 
gratefully acknowledges financial support for this project from the Social Sciences and Humanities Research Council of Canada. Ben Cashore gratefully acknowledges financial support from the Canada-US Fulbright Program and the Canadian Forest Service (Pacific Forestry Centre, Victoria). The authors also thank participants at the 1998 Canadian Institute of Forestry's annual meeting for their feedback and Donna Krejci for detailed comments on a previous version of this paper.

\section{References}

Berger, Suzanne. 1996. Introduction. In S. Berger and R. Dore (eds.). National Diversity and Global Capitalism. pp.1-8. Cornell University Press, Ithaca and London.

Canadian Council of Forest Ministers. 1998. National Forest Strategy (1998-2003). Sustainable Forests: A Canadian Commitment. Ottawa, Ontario

Canadian Press. 1998. Greenpeace Steps Up Protests in Europe Against BC Logging. Vancouver Sun, March 28, A4.

Cashore, B. 1997a. Flights of the Phoenix: Explaining the Durability of the Canada-US Softwood Lumber Dispute. CanadianAmerican Public Policy no. 32.

Cashore, B. 1997b. Governing Forestry: Environmental Group Influence in British Columbia and the US Pacific Northwest. PhD Thesis, University of Toronto.

Doern, G. B., L.A. Pal and B.W. Tomlin. 1996. The Internationalization of Canadian Public Policy. In Border Crossings: The Internationalization of Canadian Public Policy. pp. 47-49. Oxford University Press, Toronto.

Drescher, J. 1998. Process for Developing FSC Standards for the Maritime Forest Regions: FSC Maritimes Technical Standards Working Group.

Federal-Provincial/Territorial Committee of Assistant Deputy Ministers on International Forest Issues. 1996. Framework of Guiding Principles for Voluntary Certification System for Sustainable Forest Management: A Federal/Provincial/Territorial Governments of Canada Paper. Vancouver, BC.

Gale, F. and C. Burda. 1997. The Pitfalls and Potential of Eco-Certification as a Market Incentive for Sustainable Forest Management. In C. Tollefson (ed.). The Wealth of Forests: Markets, Regulation and Sustainable Forestry, pp. 414-441. UBC Press, Vancouver. Greenpeace Canada, Greenpeace International, and Greenpeace San Francisco. 1997. Broken Promises: The Truth About What's Happening to British Columbia's Forests. Greenpeace Canada, Vancouver, BC. Greenpeace International, Greenpeace, San Francisco, California.
Groen, J.P. 1994. British Columbia's International Relations: Consolidating a Coalition-Building Strategy. BC Studies, 102 (Summer): 25-9.

Hamilton, G. 1997. Don't Lower Stumpage, US tells BC. The Vancouver Sun, April 11, D1.

Hamilton, G. 1998. With Cuts, BC Stumpage Would be Double Quebec's. The Vancouver Sun, January 31, H1, H2.

Hansen, E. 1998. Chapter 3: Certified Forest Products Market Place. In United Nations Timber Committee. Forest Products Annual Market Review. United Nations Timber Committee, Geneva, Switzerland.

Horlick, G.N. and G.D. Oliver. 1989. Antidumping and Countervailing Duty Law Provisions of the Omnibus Trade and Competitiveness Act of 1988. Journal of World Trade (Law-Economics-Public Policy) 23 , no. 3: 5-49.

Humphreys, D. 1996. The Global Politics of Forest Conservation Since the UNCED. Environmental Politics, 5: 231-256.

IDRC. 1993. The Earth Summit CD-ROM. International Development Research Centre on behalf of the United Nations. Ottawa, Ontario. International Institute for Sustainable Development (IISD). 1995. Report of the First Session of the CSD Intergovernment Panel on Forests. Earth Negotiations Bulletin 13, 3 (11-5 September).

IISD. 1998. Summary of IFF-2 Geneva. Earth Negotiations Bulletin 13, 45 (August 24-September 4).

Natural Resources Canada. 1997. The State of Canada's Forests. Government of Canada, Ottawa, Ontaio.

Porter, G. and J.W. Brown. 1996. Global Environmental Politics: 2nd edition. Westview Press, Boulder, Colorado.

Schreiner, J. and P. Morton. 1997. Changes to BC Forest Code Fail to Please Environmentalists, US. The Financial Post, Wednesday, June 11,7 .

Scientific Panel for Sustainable Forest Practices in Clayoquot Sound. 1994. Progress Report 2: Review of Current Forest Practice Standards in Clayoquot Sound. British Columbia.

Williams, M. 1993. Re-articulating the Third World Coalition: The Role of the Environmental Agenda. Third World Quarterly, 14: 7-29.

World Commission on Environment and Development. 1987. Our Common Future. Oxford University Press, Oxford.

Wyden, R. 1992. Letter to Ambassador Burney. US Congress, Washington, DC. 